Article

\title{
Exploring the Critical Factors, the Online Learning Continuance Usage during COVID-19 Pandemic
}

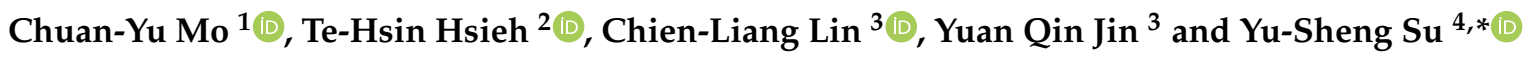 \\ 1 School of Education and Music, Sanming University, Sanming 365004, China; mochuanyu@gmail.com \\ 2 School of International Business, Tan Kah Kee College, Xiamen University, Xiamen 363105, China; \\ thsieh@xujc.com \\ 3 College of Science and Technology, Ningbo University, Cixi 315211, China; linjianliang@nbu.edu.cn (C.-L.L.); \\ jinyuanqing@nbu.edu.cn (Y.Q.J.) \\ 4 Department of Computer Science and Engineering, National Taiwan Ocean University, \\ Keelung 20224, Taiwan \\ * Correspondence: ntoucsiesu@mail.ntou.edu.tw
}

Citation: Mo, C.-Y.; Hsieh, T.-H.; Lin, C.-L.; Jin, Y.Q.; Su, Y.-S. Exploring the Critical Factors, the Online Learning Continuance Usage during COVID-19 Pandemic. Sustainability 2021, 13, 5471. https://doi.org/ $10.3390 /$ su13105471

Academic Editors: Teen-Hang Meen, Charles Tijus and Jui-Che Tu

Received: 27 March 2021

Accepted: 6 May 2021

Published: 13 May 2021

Publisher's Note: MDPI stays neutral with regard to jurisdictional claims in published maps and institutional affiliations.

Copyright: (c) 2021 by the authors. Licensee MDPI, Basel, Switzerland. This article is an open access article distributed under the terms and conditions of the Creative Commons Attribution (CC BY) license (https:// creativecommons.org/licenses/by/ $4.0 /)$.

\begin{abstract}
In order to enable online learning to continue developing when the COVID-19 pandemic passes, this study aimed to identify the critical factors that affected the use of e-learning by university students during the pandemic. These critical factors will help to increase the efficiency of future development and deployment of online learning systems. Through a literature review, this study employed the technology acceptance model, social support, and task-technology fit as the theoretical basis to establish the framework of the online learning environment with regards to the technology acceptance model in the context of emergency management. A questionnaire survey was administered to students in universities that had implemented online teaching during the pandemic, and 552 valid responses were collected. The survey explored the factors affecting the willingness of higher education institution students to continue using online learning, and the following conclusions were drawn. (1) The easier an online learning platform was to navigate, the better it was perceived by the students, and thus the students were more willing to use it. (2) Ease of use and usefulness were associated with the teachers' choice of platform and their ability to achieve a satisfactory fit between the course design and platform navigation, which thereby affected the students' learning outcomes and attitude towards use. (3) The positive attitude of teachers towards teaching increased the students' perceived ease of use of online learning. (4) During the pandemic, family support-a major support for teachers in online teaching — enhanced teachers' attitudes towards, and willingness to provide, online teaching. A high level of support showed that the parents urged the students to learn and complete online learning tasks as instructed by the teachers, implying that family support could affect the students' habits towards, adaptation to, and identification of online learning. The study results provide insights into the factors affecting the willingness of teachers and students to continue using e-learning platforms.
\end{abstract}

Keywords: COVID-19; technology acceptance model; e-learning; task-technology fit

\section{Introduction}

During the COVID-19 pandemic, most universities have become aware of the features of online teaching and learning, and thus have actively encouraged teachers across all levels of education to promote online learning. During the pandemic, the Ministry of Education, to reduce the risk of being infected by going out, released the Guidelines on Organization and Management of Online Teaching of General Institutions of Higher Education During Epidemic, and required that institutions of higher education should not suspend education, although offline classes were suspended, but should actively offer online classes to ensure the smooth continuation of teaching and the improvement of teaching quality during the pandemic [1]. It later released the Notice on Coordinating COVID-19 Epidemic Prevention and Control and 
Education Reform and Development in the Education System to require that institutions of higher education should provide better guidance on learning from home when students were taking classes at home [2].To this end, the Ministry of Education announced platforms of course resources and technologies for online teaching according to the conditions of universities under COVID-19 pandemic prevention to facilitate the selection of suitable platform systems according to their pedagogical features [3]. The pandemic has forced a rapid shift in higher education toward distance and online learning. However, China is a vast country, and the economic gap and uneven development between different regions has become the main obstacle for online education, which is more significant in rural areas such as the northwest or the west of China where there is a shortage of resources and a lack of sufficient teachers, equipment, and technical support [4]. In addition, a talent shortage in western regions hinders the implementation of online teaching. Teachers are insufficiently informed, with some sticking to only one existing teaching method. The aforementioned difficulties considerably reduce student enthusiasm for learning, inevitably causing imbalances in the development of distance education, and negatively affecting higher education [5]. This has had numerous consequences, such as challenges for pedagogical workers and learners, a lack of knowledge about information and communications technology, poor network infrastructure, and weak content development inevitably affecting the general adoption of online learning [6]. In this regard, students using online learning are susceptible to external factors influencing online learning. These factors can decrease satisfaction with online learning and prevent its continued use [7].

During the pandemic, university students were required to take online classes given by respective institutions according to the policy of the Ministry of Education, thus the utilization of online education increased significantly. However, whether online education will be as desirable without such external support and whether such external support will lead to its continued use in the future is a topic worth discussing. Particularly with regard to the COVID-19 pandemic, various countries are endeavoring to shift traditional classroom teaching to online learning in an attempt to strengthen social distancing measures and maintain normal school operations. Thus, the use of various forms of online learning is strongly advocated. However, such a radical approach has exposed inadequacies in online teaching, such as the limited feedback of students about online teaching, the lack of a valid course certification processes as well as scientific and high-quality content, and insufficient student self-motivation and commitment, all leading to a sudden decline in students' intention to use online learning following the pandemic [8]. Thus, maintaining the stable development of online teaching following the pandemic requires the determination of the key factors influencing its use and suggested measures for improvement. In this respect, a review of prior studies revealed that, whether online learning successfully becomes an educational tool depends mainly on students' intention to use and accept the e-learning systems [9]. Thus, to understand students' opinions and adoption intentions regarding online learning systems, the effect of external factors should be considered, and these factors should be examined through consideration of environmental features [6]. The technology acceptance model (TAM) has provided a theoretical base for studies on the intention to adopt and use online learning systems [10]. The theory has been widely applied to challenges in the national implementation of numerous types of online learning [11-14].

A review of studies on online learning suggests that platform quality (e.g., the quality of content, system stability, and technical support), students' personal factors (e.g., student attitude and the effect of immersion), and the quality of teaching (e.g., the timing of instructor response, instructor attitude (IAT) towards online learning, and interaction and communication between instructors and students) are the main factors by which researchers make conclusions $[6,15,16]$. However, during the current pandemic, students are spending time at home engaging in online learning, indicating that three aspects, namely, family, students, and the teacher, may be crucial indicators of students' intention to use online learning. These three aspects have rarely been jointly discussed. Thus, this study focused on higher education institutions in China and expanded the TAM framework to 
examine how family, the teacher, and the students themselves influenced the use of online learning among students affected by COVID-19 and whether students' intention to use online course platforms will continue.

\section{Literature Review}

\subsection{Technology Acceptance Model}

The TAM was proposed by Davis to explain how people's attitude and behavior predict the adoption of a technology with the presence of other external variables [10]. The model is frequently applied in usage behavior research in attempts to comprehend the reasons for the acceptance or rejection of an information system. In teaching, information technology plays a prominent role because it can encourage innovation, provide new learning spaces, and transform instructional activities [17-19], all of which are closely associated with the ease of information technology operation. Ease of operation-convenience in the user experience and whether the user can proficiently command and use digital information and communications technologies-directly affects user perceptions and motivation to learn [20]. Studies have demonstrated the positive effect a student's proficient command of information technology has on learning performance [21]. A review of the relevant literature indicated that the TAM has been widely applied in studies of online learning. The literature is synthesized in Table 1.

Table 1. Research topics on the technology acceptance model (TAM).

\begin{tabular}{|c|c|c|c|}
\hline Authors & Research Contexts & Constructs & Fundamental Theories \\
\hline $\begin{array}{c}\text { Baby \& } \\
\text { Kannammal [22] }\end{array}$ & e-learning & $\begin{array}{c}\text { Perceived Usefulness, Perceived Ease of Use, Perceived } \\
\text { Trust, Perceived Security, Perceived Privacy, } \\
\text { Information Quality }\end{array}$ & TAM \\
\hline $\begin{array}{c}\text { Ayele \& } \\
\text { Birhanie [23] }\end{array}$ & e-learning & Training, top management support, incentive & TAM \\
\hline Ashrafi et al., [14] & $\begin{array}{l}\text { Learning management } \\
\text { system }\end{array}$ & $\begin{array}{l}\text { Subjective norm, enjoyment, confirmation, satisfaction, } \\
\text { content quality, navigation, presentation }\end{array}$ & $\mathrm{ECT}+\mathrm{TAM}$ \\
\hline $\begin{array}{l}\text { Chang, Hajiyev, \& } \\
\text { Su [24] }\end{array}$ & e-learning & $\begin{array}{l}\text { Self-efficacy, subjective norm, enjoyment, computer anxiety, } \\
\text { technological innovation, experience }\end{array}$ & $\begin{array}{l}\text { ECT }+ \text { IS success model }+ \\
\text { continuance theory }\end{array}$ \\
\hline $\begin{array}{l}\text { Francis B. } \\
\text { Osang et al. [25] }\end{array}$ & e-learning & $\begin{array}{c}\text { systems in terms of attitude towards use, IT usage, user } \\
\text { satisfaction and performance }\end{array}$ & $\mathrm{TAM}+\mathrm{TRA}+\mathrm{IS}$ \\
\hline $\begin{array}{l}\text { Scherer, Siddiq, \& } \\
\text { Tondeur [26] }\end{array}$ & e-learning & $\begin{array}{c}\text { Facilitating conditions, subjective norms, } \\
\text { technology self-efficacy }\end{array}$ & TAM \\
\hline $\begin{array}{l}\text { Weng, Tsai, \& } \\
\text { Weng [27] }\end{array}$ & e-learning & $\begin{array}{l}\text { e-learning self-efficacy, managerial support, peer support, } \\
\text { family support }\end{array}$ & TAM + social support theory \\
\hline Wu \& Chen [28] & MOOCs & $\begin{array}{l}\text { Individual-technology fit, task-technology fit, openness, } \\
\text { reputation, social influence, social recognition }\end{array}$ & $\mathrm{TAM}+\mathrm{TTF}$ \\
\hline $\begin{array}{l}\text { Vanduhe, Nat, \& } \\
\text { Hasan [29] }\end{array}$ & $\begin{array}{l}\text { Gamification for training in } \\
\text { higher education }\end{array}$ & Social influence, task-technology fit, social recognition & $\mathrm{TAM}+\mathrm{TTF}$ \\
\hline $\begin{array}{l}\text { Pozón-López } \\
\text { et al. [30] }\end{array}$ & MOOCs & $\begin{array}{l}\text { Vividness of content, interactivity, controlled motivation, } \\
\text { autonomous motivation, entertainment, course quality, } \\
\text { emotions, satisfaction }\end{array}$ & TAM \\
\hline Lee [31] & e-learning & $\begin{array}{c}\text { Confirmation, satisfaction, enjoyment, concentration, } \\
\text { subjective norm, behavior control }\end{array}$ & $\begin{array}{l}\mathrm{ECT}+\mathrm{TAM}+\mathrm{TPB}+ \\
\quad \text { Flow theory }\end{array}$ \\
\hline $\begin{array}{l}\text { Zhonggen \& } \\
\text { Xiaozhi [32] }\end{array}$ & Mobile learning & $\begin{array}{c}\text { Peer influence, superior influence, enjoyment, subjective } \\
\text { norm, image, job relevance, output quality, result } \\
\text { demonstrability, adjustment, experience, } \\
\text { anchor, voluntariness }\end{array}$ & TAM2 \\
\hline Al-Rahmi et al. [33] & MOOCs & $\begin{array}{l}\text { Compatibility, trainability, complexity, observability, } \\
\text { relative advantage }\end{array}$ & $\mathrm{TAM}+\mathrm{IDT}$ \\
\hline Sun \& Gao [34] & Mobile learning & Intrinsic motivation, task-technology fit & $\begin{array}{l}\mathrm{TAM}+\mathrm{TTF}+ \\
\text { intrinsic motivation }\end{array}$ \\
\hline Cheng [35] & e-learning & Subjective norm, behavior control, self-esteem & $\mathrm{TAM}+\mathrm{TPB}$ \\
\hline $\begin{array}{l}\text { Romero-Frías } \\
\text { et al. [36] }\end{array}$ & MOOCs & Loyalty, external regulation, intrinsic motivation & $\begin{array}{c}\text { TAM }+ \text { self-determination } \\
\text { theory }\end{array}$ \\
\hline
\end{tabular}

A review of these studies revealed that most approached and examined topics from the angles of platform, students' personal factors, peer factors, or quality of teaching $[14,18,24,37-39]$. As suggested by Benbasat and Barki [40], TAM-themed studies should focus on determining the antecedents of perceived usefulness (PU) and the 
consequences-of-use behavior to propose a more comprehensive model. Thus, three expanded variables, namely, family support (FS), task-technology fit (TTF), and IAT, were adopted as the main external variables for the current study.

\subsection{Family Support (FS)}

Social support reflects how an individual is willing to become a member of a group because she/he feels respected and valued during interpersonal interaction [41]. Social factors are affected by the cultural background of a group, and an individual is prompted to behave according to group norms, which further affects the individual's beliefs. Social influence is formed when the beliefs of a group are sufficiently accumulated; it determines the extent to which an individual perceives the "right" thing to do according to the opinions of others [42]. An individual's faith, beliefs, and behavior are affected by the admonition of others [43]. An individual experience of being cared for, responded to, and helped in a social group when they are directly or indirectly influenced by others was termed by Cobb and Sidney as "social support". [44] Through this support, an individual can obtain help (through interaction with others) and thus feel a sense of belonging and cohesion, which indirectly affects their intention to use online learning [45]. Huang et al. suggested that social support has a multidimensional structure, and its components might differ according to environments [17]. Cheng and Chan suggested that social support per se implies three aspects, namely, the support of family, friends, and others, and, through these forms of support, social support is reflected as being multifaceted [46].

Both teachers and families provide social support to students engaging in online learning. Regarding teacher support, studies have indicated that the number of perceived benefits of online learning increases when teachers support students and interact with them online [47]. Harvey et al. and Maurer et al. indicated that FS greatly affects learning satisfaction, particularly in continuing professional education [48,49]. As elaborated by Weng et al. [27], for a company employee participating in online learning, the frequency of their continued use of online learning increases with FS. In the university context, family factors are typically ignored in consideration of conventional online learning mainly because the majority of university curriculums are offline with only one or a few courses online. Second, the lives of Chinese students revolve around the campus, as most live on campus. However, online learning during the pandemic differs from the online teaching method pre-pandemic; it represents a new online learning model. The living environment of students has shifted from the campus to their family home. In particular, due to the delay in work resumption for most parents during the pandemic, many parents are at home most of the time and supervise or accompany students engaging in online learning [50]. Thus, during the pandemic, FS has played a prominent role in online learning.

\subsection{Instructor Attitude}

By definition, IAT involves how the instructor's attitude is perceived by a student, as well as an instructor's real-time response, teaching style, and attitude in helping the student through online learning platforms [51-53]. Thus, IAT involves an instructor's real-time feedback on student questions $[54,55]$ to reduce learning gaps and build a more comprehensive learning mechanism. An essential aspect of IAT consists of the instructor conceiving of a series of instructional activity designs and learning resources and encouraging effective learning through interaction and exchange, and with appropriate instructional tools [56]. In online learning courses, a positive IAT contributes to continuous learning, and learning outcomes are improved when the instructor's response to student needs and inquiries is rapid [57]. Thus, the exhibition of a positive attitude, a passion for teaching, and the assistance and guidance of students affect student intention to use online learning systems [16]. In studies extending the TAM, Lwoga as well as Rodríguez-Ardura and Meseguer-Artola elaborated on the antecedents affecting online learning and proposed combining IAT with the TAM to explore students' intention to adopt online learning $[56,58]$. Given the pandemic in the context of the present study, online learning has been adopted 
for all courses and IAT is crucial. In this period, instructor engagement is a particularly crucial factor that indirectly prompts students to accept online learning.

\subsection{Task-Technology Fit}

From the viewpoint of TTF theory, technology implies computer systems as well as support and services meeting user needs; tools are provided to assist users in performing tasks [59]. The theory is intended to explain how technology adoption is affected by technology and task characteristics [60]. In the TTF model, technology utilization rate and perceived TTF increase with the amount of support provided by technology for a user's task [61]. Thus, correspondence between a task and an online learning system user's needs contributes to maximal learning results $[11-13,62,63]$. In TTF, importance is placed on the influence of task characteristics, which, in the context of TAM, is another approach to explaining technology adoption. Numerous researchers have attempted to integrate TTF and TAM to investigate technology adoption in online learning $[28,29,34]$. When technology closely fits a task, a good result can be expected. Thus, TTF theory compensates for the insufficient focus on the role of tasks in the TAM. In addition, studies have indicated that integrating TTF and the TAM can predict a change in technology adoption more reliably than either TTF or the TAM alone [64,65]. Moreover, such integration is similar to perceived usefulness and perceived ease of use (PEU), and TTF is considered an external motivation factor in technology adoption due to its close association with external goals [66]. Consequently, from the perspective of student learning, the implementation of online learning in China during the COVID-19 pandemic employed e-learning to meet the needs of closed schools, where teaching through offline courses was unfeasible. Thus, understanding whether the teacher's choice of online learning platforms or their adoption of various types of online courses corresponds with student needs is crucial both to understanding e-learning during the pandemic and to its future development.

\section{Research Model and Hypotheses}

\subsection{Research Model}

Prior research suggests that an extension of the TAM can provide a stronger explanation for the behavior under study [29,67-69]. Venkatesh and Davis also confirm the applicability of this model in both voluntary and mandatory contexts [69]. Benbasat and Barki suggest that future adoption research should place more emphasis on the factors that impact antecedents of the belief [40]. The research model is shown in Figure 1. In this section, the theoretical model based on previous research and literature is proposed in the current study. Subsequently, the hypotheses of the study are listed below.

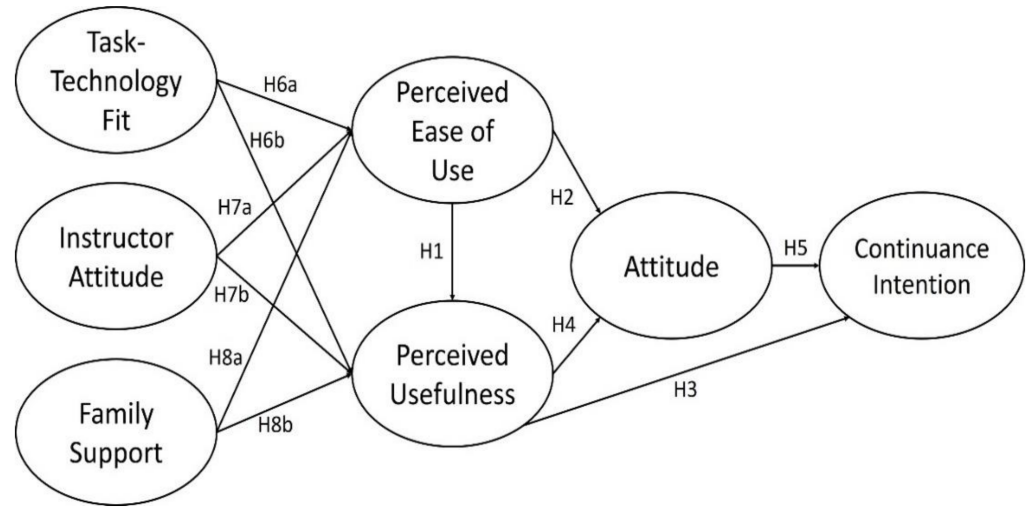

Figure 1. Research model.

\subsection{Hypotheses}

Davis et al. [10] proposed the TAM and held that PU and PEU affect the user in terms of attitude toward use. PU is affected by ease of use; one's attitude toward using technology and their intention to use determine whether the user will adopt the technology. The TAM has 
been widely used for empirical purposes in studies in information management [28,70-72]. Most studies on online learning have proved that PEU affects PU, PU and PEU positively affect attitude, and attitude and PU affect continued use [16,29,73]. Hypotheses 1 through 5 were formulated according to the theoretical basis of the TAM:

H1. Perceived ease of use has a positive effect on the perceived usefulnessof using online learning.

H2. Perceived ease of use has a positive effect on attitude towards using online learning.

H3. Perceived usefulness has a positive effect on continuance intention to use online learning.

H4. Perceived usefulness has a positive effect on attitude towards using online learning.

H5. Attitude has a positive effect on continuance intention to use online learning.

People's understanding of a system is based on their knowledge and experience $[69,74,75]$. In attempting to complete tasks using technology, people rationally assess its advantages, gradually adopt efficient behavior, and construct opinions and perspectives on the system. Researchers have proved that TTF affects both the usefulness and the ease of use of online learning $[29,34]$. According to the argument of Dishaw and Strong [76], when a user finds that an information system involves numerous inextricable functions, they naturally perceive learning to use it as being much more difficult than learning to use a system with simple functions. After a while, as a user gradually perceives a system to have good TTF, its functions are considered capable of meeting the requirements of a task, which naturally improves the perceptions of the system's usefulness. Because ease of use affects usefulness and because technological functions and task requirements should fit, the user should perceive a certain degree of ease of use. The following hypotheses were formulated accordingly:

H6a. Task-technology fit has a positive effect on the perceived ease of use of online learning.

H6b. Task-technology fit has a positive effect on the perceived usefulness of online learning.

Regarding IAT towards teaching, previous studies have indicated that this attitude has a crucial influence on student usage $[16,52,56]$. In a pandemic, IAT can encourage students to agree to use online learning by highlighting its usefulness and ease of use. Thus, hypotheses $7 \mathrm{a}$ and $7 \mathrm{~b}$ were formulated.

H7a. Instructor attitude has a positive effect on the perceived ease of use of online learning.

$\mathbf{H 7 b}$. Instructor attitude has a positive effect on the perceived usefulness of online learning.

Weng et al. [27] reported that FS contributes to an increase in the frequency of online learning. Research on technology acceptance emphasizes how social influence affects student attitude and efforts regarding technology. Social influence describes the extent to which students perceive the opinions of significant others, namely, peers, teachers, and parents [77]. Studies have revealed that social influence does not affect student attitude towards computers and the use of other devices because society's overall positive views cancel the effect of these forms of social influence [78,79]. However, Zheng and Li [80] demonstrated that in student acceptance of computers and the use of other devices, FS was a significant predictor of usefulness and ease of use. Overall, as students stayed at home and followed online courses during the pandemic, this study reasonably assumed that supporting students in their use of computers in online learning induced a positive effect on the students' perceived usefulness and ease of use of online learning. Thus, hypotheses $8 \mathrm{a}$ and $8 \mathrm{~b}$ were formulated:

H8a. Family support has a positive effect on the perceived ease of use of online learning.

H8b. Family support has a positive effect on the perceived usefulness of online learning. 


\subsection{Construct Operationalization}

In terms of the choice of scales, the items of Gefen [81] were adopted and adjusted for perceived usefulness, the items of Mohammadi [82] were used for perceived ease of use, the items of Hsu, Chen, and Ting [39] were employed for attitude, the items of RodríguezArdura and Meseguer-Artola [56] were used for instructor attitude, the items of Ashrafi et al. [14] were used for continuance intention, the items of Weng, Tsai, and Weng [27] were used for family support, and the items of Isaac et al. [12] were used for task-technology fit.

\subsection{Data Collection}

Through the WJX platform, an online questionnaire survey was administered in 18 universities in China that implemented full online teaching during the pandemic period. The questionnaire was distributed to 857 students between May and June 2020, during which the final exams took place. Because offline surveys could not be performed during this period, convenience sampling was adopted to select students. Members in the chat groups of university teachers created in WeChat and Tencent QQ were invited to distribute the questionnaire to their students. To improve the sample quality, the following four principles proposed in previous studies [83-85] were used to screen for valid samples. First, respondents require 8-15 min to complete the questionnaire, thus, samples that were completed within 3 min were considered invalid. Second, samples with outlier values or identical answers throughout the questionnaire were excluded. Third, samples with the same IP address were excluded by the WJX platform. Finally, reverse questions were designed to identify respondents who provided their answers randomly. According to these principles, 305 invalid responses were excluded, and a total of 552 valid responses were collected, including 156 male and 396 female samples. Of these respondents, 74 were male. Table 2 details the respondents' demographics. Among them, 182 students used online learning for $1 \mathrm{~h}$ every day, 112 students for 1 to $2 \mathrm{~h}$ every day, 156 students for 2 to $4 \mathrm{~h}$ every day, and 102 students for more than $4 \mathrm{~h}$ every day. Prior to the COVID-19 pandemic outbreak, $55 \%$ of students reported zero experience with e-learning and $45 \%$ of students had more than six months of experience.

Table 2. Factor loading, alpha, composite reliability, and average variance extracted (AVE).

\begin{tabular}{|c|c|c|c|c|c|}
\hline Construct & Factor Loading & $\alpha$ & CR & AVE & VIF \\
\hline Perceived usefulness & $\begin{array}{l}0.943^{* * *} \\
0.949^{* * *} \\
0.894^{* * *}\end{array}$ & 0.882 & 0.943 & 0.895 & 2.337 \\
\hline Perceived ease of use & $\begin{array}{l}0.924^{* * *} \\
0.941^{* * *} \\
0.913^{* * *}\end{array}$ & 0.909 & 0.944 & 0.846 & 1.722 \\
\hline Attitude & $\begin{array}{l}0.898^{* * *} \\
0.885^{* * *} \\
0.956^{* * *}\end{array}$ & 0.881 & 0.926 & 0.808 & 1.552 \\
\hline Continuance intention & $\begin{array}{l}0.958^{* * *} \\
0.947^{* * *} \\
0.875^{* * *}\end{array}$ & 0.950 & 0.927 & 0.909 & DV \\
\hline Instructor attitude & $\begin{array}{l}0.908^{* * * *} \\
0.912^{* * *} \\
0.903^{* * * *}\end{array}$ & 0.882 & 0.968 & 0.807 & 2.249 \\
\hline Family support & $\begin{array}{l}0.903^{* * *} \\
0.908^{* * *} \\
0.892^{* * *} \\
0.850^{* * *}\end{array}$ & 0.911 & 0.937 & 0.789 & 2.253 \\
\hline Task-technology fit & $\begin{array}{l}0.914^{* * *} \\
0.938^{* * *} \\
0.914^{* * *} \\
0.854^{* * *}\end{array}$ & 0.926 & 0.948 & 0.820 & 1.945 \\
\hline
\end{tabular}

Notes: VIF (variance inflation factor); AVE (average variance extracted); DV (dependent variable); ${ }^{* * *}$ significant at $p<0.01 ; \mathrm{CR}$ (composite reliability). 


\section{Results}

This study applied SPSS and SEM-PLS for measurement and structural model analysis of the collected data. Furthermore, regarding multicollinearity, Hair et al. [86] suggested the variance inflation factor (VIF) value below 5. Results indicate that VIF ranged from 1.552 to 2.337 , thus indicating that multicollinearity meets the requirements (see Table 2).

\subsection{Measurement Model}

In reliability and validity analyses of the measurement model, the main indicators for assessment were factor loading, composite reliability, convergent validity, and discriminant validity [87-89]. Reliability for each item was assessed and analyzed mainly through factor loading and Cronbach's $\alpha$. According to suggestions in the literature, all construct outcome values and the factor loading of each item should be greater than 0.7 [90]. Cronbach's $\alpha$ value was greater than 0.7 . Regarding composite reliability, studies have suggested that the indicator value be greater than 0.7 [91]. When measuring convergent validity, the average variance extracted (AVE) of each construct needed to exceed 0.5. Table 2 shows that all the AVEs exceeded 0.5, indicating satisfied convergent validity.

The goal of verification discriminant validity is to examine any discrepancy of measurement variables concerning the constructs. The square root of the AVE for each construct must be greater than the correlation coefficients between constructs [92]. Table 3 presents the correlation coefficient matrix of the constructs. The values along the diagonal line represent the square roots of the AVE values. The square root values of the AVE were greater than the correlation coefficients between the constructs, indicating that the results for each construct good discriminant validity.

Table 3. Analysis of discriminant validity.

\begin{tabular}{cccccccc}
\hline & AT & CIT & PEU & PU & TTF & FS & IAT \\
\hline AT & 0.899 & & & & & & \\
CIT & 0.723 & 0.954 & & & & & \\
PEU & 0.639 & 0.520 & 0.920 & & & & \\
PU & 0.756 & 0.674 & 0.596 & 0.946 & & & \\
TTF & 0.807 & 0.668 & 0.621 & 0.758 & 0.905 & & \\
FS & 0.653 & 0.496 & 0.609 & 0.538 & 0.593 & 0.888 & \\
IAT & 0.657 & 0.376 & 0.603 & 0.513 & 0.598 & 0.693 & 0.899 \\
\hline
\end{tabular}

Notes: Attitude (AT); continuance intention (CIT); perceived ease of use (PEU); perceived usefulness (PU); task-technology fit (TTF); instructor attitude (IAT); family support (FS).

\subsection{Structural Model}

To test the research hypotheses, the bootstrap resampling method in SmartPLS was used to evaluate the PLS results, with the responses resampled 5000 times [90]. The overall $\mathrm{R}^{2}$ value of our results was $55.9 \%$. The $\mathrm{R}^{2}$ for ease of use was $49.6 \%$, the $\mathrm{R}^{2}$ for attitude was $62.6 \%$, and the $\mathrm{R}^{2}$ value for usefulness was $60 \%$ (Figure 2). The results indicate that the research model proposed for the study has high explanatory power.

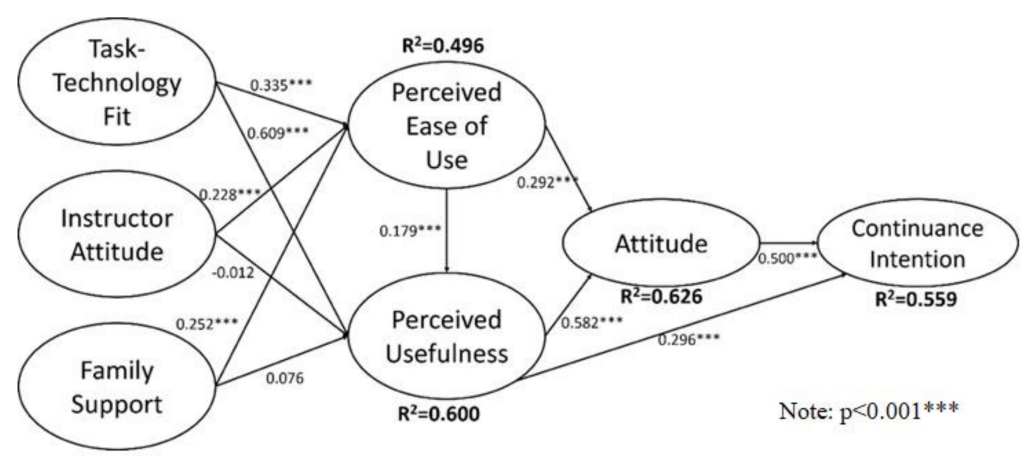

Figure 2. PLS results of the research model (Note: $p<0.001^{* * *}$ ). 
The result supports $\mathrm{H} 1$ to H6a, H7a, and H8a. Perceived ease of use has a positive significant influence on perceived usefulness $(p<0.01)$, thus supporting H1. Perceived usefulness has a positive significant influence on attitude $(p<0.01)$, thus supporting H4. Perceived usefulness has a positive significant influence on continuance intention $(p<0.01)$, thus supporting H3. Perceived ease of use on attitude (H2) was significant at $p<0.01$. Attitude has a significant influence on continuance intention, thus supporting $\mathrm{H} 5$.

The results showed that task-technology fit has a significant influence on perceived ease of use (H6a) and perceived usefulness (H6b), which provides support for H6a and H6b, respectively. The study found that instructor attitude significantly influences perceived ease of use (H7a) and perceived usefulness (H7b). Finally, we also found that family support has a significant influence on perceived ease of use (H8a), and perceived usefulness $(\mathrm{H} 8 \mathrm{~b})$ was not significantly supported.

\section{Discussion and Conclusions}

\subsection{Discussion}

According to the research results, PEU, PU, and attitude regarding the use of online learning during the pandemic achieved statistical significance, and all of them have been proven to be prominent predictors $[14,25,37]$. Differing from those in prior studies on online learning, the online learning resources of higher education institutions in China during the pandemic were largely learning platforms provided by the Ministry of Education (MOE) of the People's Republic of China [3]. Additionally, because the platforms were provided by the state, when the platform interface was simple to use and the content contained materials useful for learning, online courses were perceived by university students as being more helpful. Second, ease of platform operation can induce a positive attitude towards using a platform. Regarding the implementation of online learning during the pandemic, universities may conceive diverse approaches to focusing on student needs, improving the quality of course content in learning systems, and strengthening the operation interface. Universities can enhance student attitudes and their continuance intention by simplifying system processes and improving the practicality of course content. Furthermore, the result suggesting that TTF had a significant influence on PEU and PU concurs with previous reports $[28,29]$. Under the impact of COVID-19 and at a time when the fit between task and technology greatly affected the use of online learning, whether the current approaches to conducting courses correspond to the goals of students particularly affects their use of online learning platforms. Thus, teachers and educational institutions should consider deploying course content according to course requirements and types, thereby enabling easy operation and encouraging students to perceive the learning as useful.

In addition, this study discovered that IAT had a significant effect on PEU but not on PU, whereas the literature reported otherwise [58,93-95]. Doubtlessly, feedback regarding a teacher's instruction via online platforms and their timely response to, and interaction with, students are elements indispensable to the success of online learning systems [17,51,52]. For online courses during the COVID-19 pandemic, the effects of teacher-student interaction, course guidance, and teacher responses to questions were crucial in improving learning outcomes. However, in online learning platform use, ease of platform operation determined whether students completed assignments.

Finally, this study reported that the effect of FS on PEU was statistically significant, but FS had no direct effect on PU. This finding contains two implications regarding FS in this context. FS was not the main influence on the perceived usefulness of online learning among the students. According to the survey results, the main impact factor was arguably the necessity of online teaching during the pandemic leading to its extensive implementation on campuses in China; online courses are necessary for students to complete so-called learning performance appraisals by performing online tasks while following teacher instructions and meeting university requirements. Therefore, although the effect of FS on PU was non-significant, FS functioned as auxiliary supervision and thus indirectly affected PU, 
indicating that, in the context of student use of online learning platforms, FS is affected by PEU.

\subsection{Practical Implications}

This study addressed the continuance intention of university students for online learning in China during the COVID-19 pandemic. With the online learning environments built in the context of emergency management, the post-COVID-19 era is propitious for expanding online learning. Because COVID-19-induced online learning differs to some extent from conventional online learning, this study used SF, TTF, and IAT as expanded variables to investigate the TAM structure of online learning environments during emergency management, as well as their influence on the continuance intention of students.

From a theoretical perspective, the combination of TTF and TAM has been thoroughly explained; TTF has direct effects on both PEU and PU in online learning environments [29]. The present findings indicate that teachers' choice of online learning platform and their subsequent deployment of course content during the pandemic directly affected the perceived usefulness and ease of use for students using the platform. In particular, the course curriculum and design were perceived by the students as easier to grasp when the fit between the design and the platform was closer, which in turn improved learning effectiveness, provided assistance in learning, and increased students' positive attitude toward online learning. This indicated that teachers must select suitable online teaching platforms according to the characteristics of the subjects they are teaching. For example, mathematics and statistics courses involve the teaching of calculation processes; hence, the requirements of platforms used to teach these subjects are more complex than those of the platforms used to teach subjects that solely involve textual description. Crucial discussion topics emerge regarding how teachers and students can use two-dimensional screens to examine abstract logic and equations, and how extra learning burdens caused by difficulty with using an online platform can be alleviated to encourage students to engage in active learning. In addition, regarding the correlation of IAT with PU and PEU, a significant correlation between IAT and PEU but not PU was present. This result differed from that of a previous report where PU and PEU were both significantly correlated with IAT [56]. An inference from the result is that students are relatively motivated to acquire knowledge when the teacher provides appropriate learning materials, conducts relevant learning activities, and provides timely and effective instruction and support through a process of continuous exchange and interaction. Thus, the teacher's positive approach to online teaching and learning is motivating and induces a perceived ease of use of online learning systems among students.

Finally, the MOE implemented policies for students to learn at home during the pandemic. This allowed parents to observe the learning status of their children as well as the teaching styles of the teachers. When parents witness a favorable interaction between their children and teachers during online learning, they are more willing to trust and accept this teaching mode and encourage the children to learn. According to Harvey et al. [48], FS prompts parents to spur students on to learn. Because online teaching prevents comprehensive supervision by teachers, FS can be a major supporting factor for teacher instruction, and the auxiliary support it provides enhances, to an extent, the teacher's intention to engage in online teaching and to invest in online teaching work. Stronger FS during the pandemic represented greater parental supervision and parental help with resolving problems in courses. Thus, students were able to complete online tasks designed by their teacher. Moreover, teachers are likely to put more effort into their teaching and pay closer attention to learning outcomes when they know that students' parents are watching and supporting them. Accordingly, students can receive more learning resources. This improves students habits and increases the need to use online learning, in addition to improving the suitability of online learning. Without FS, students are susceptible to distractions from online learning, such as mobile phone games, television dramas, and social software, which disrupt their intention to use and eventually prevents them from completing assigned tasks. Accordingly, students stop using platforms they perceive as irrelevant and difficult to use. 


\subsection{Limitations and Future Research}

This study had limitations. First, the sampling in various regions was constrained due to the adoption of snowball and convenience sampling. Thus, it is suggested that subsequent studies focus on collecting samples from various regions so that the results can be more be generalizable. Second, the study conducted a survey, but the data were collected during a pandemic. Investigations into promoting the continuance intention of online learning in the context of emergency management is probably beyond the scope of future work. Therefore, qualitative research methods may be adopted in the future to facilitate the determination of continuance intention of online learning in the post-COVID-19 pandemic era to come [96-98].

Author Contributions: The authors contributed equally to the conception of the idea, implementing and analyzing the experimental results, and writing the manuscript. All authors have read and agreed to the published version of the manuscript.

Funding: This research was supported by the Starting Research Fund from the Sanming University (19YG15S), Sanming University's higher education research project (SHE1914), K.C. Wong Magna Fund in Ningbo University (RC190015), Ningbo Education Science Planning (2020YQZX173), The provincial "Qinyuan" innovation and entrepreneurship comprehensive experimental teaching center key construction project of the 13th five-year plan of Zhejiang Province (Zhejiang Education Office 2019 (218)). In addition, this study was supported by the Ministry of Science and Technology, Taiwan, R.O.C., under grant MOST 109-2511-H-019 -004 -MY2 and MOST 109-2511-H-019-001.

Institutional Review Board Statement: Not applicable.

Informed Consent Statement: Informed consent was obtained from all subjects involved in the study. Data Availability Statement: Not applicable.

Conflicts of Interest: The authors declare no conflict of interest.

\section{References}

1. Ministry of Education of the People's Republic of China. Guidelines on Organization and Management Online Teaching of General Institutes of Higher Education During Epidemic. 2020. Available online: http:/ /www.moe.gov.cn/jyb_xwfb/s5147/20 2002/t20200206_418480.html. (accessed on 1 February 2021).

2. Ministry of Education of the People's Republic of China. Control and Education Reform and Development in the Education System. 2020. Available online: http://www.moe.gov.cn/srcsite/A17/s7059/202002/t20200228_425499.html (accessed on 28 February 2021).

3. Cheng, X. Challenges of 'School's Out, But Class's On' to School Education: Practical Exploration of Chinese Schools during the COVID-19 Pandemic. Sci. Insigt. Edu. Front. 2020, 5, 501-516. [CrossRef]

4. Ting, S.R.; Smith, A.C.; Gomez, E. E-learning in China: Progress, Challenges, and Research Issues. In Digital Transformation Innovation in Chinese Education; IGI Global: Hershey, PA, USA, 2018. [CrossRef]

5. Wang, Q.; Zhu, Z.; Chen, L.; Yan, H. E-learning in China. Campus Wide Inf. Syst. 2009, 26, 77-81. [CrossRef]

6. Kanwal, F.; Rehman, M. Factors affecting e-learning adoption in developing countries-empirical evidence from Pakistan's higher education sector. IEEE Access 2017, 5, 10968-10978. [CrossRef]

7. Tarhini, A.; Hone, K.; Liu, X.; Tarhini, T. Examining the moderating effect of individual-level cultural values on users' acceptance of E-learning in developing countries: A structural equation modeling of an extended technology acceptance model. Interact. Learn. Environ. 2017, 25, 306-328. [CrossRef]

8. García Vazquez, A.; Verde, J.M.; Dal Mas, F.; Palermo, M.; Cobianchi, L.; Marescaux, J.; Gallix, B.; Dallemagne, B.; Perretta, S.; Gimenez, M.E. Image-Guided Surgical e-Learning in the Post-COVID-19 Pandemic Era: What Is Next? J. Laparoendosc. Adv. Surg. Tech. 2020. [CrossRef]

9. Almaiah, M.A.; Al Mulhem, A. Analysis of the essential factors affecting of intention to use of mobile learning applications: A comparison between universities adopters and non-adopters. Educ. Inf. Technol. 2019, 24, 1433-1468. [CrossRef]

10. Davis, F.D. Perceived Usefulness, Perceived Ease of Use, and User Acceptance of Information Technology. MIS Q. 1989, 13, 319-340. [CrossRef]

11. Kissi, P.S.; Nat, M.; Armah, R.B. The effects of learning-family conflict, perceived control over time and task-fit technology factors on urban-rural high school students' acceptance of video-based instruction in flipped learning approach. Educ. Technol. Res. Dev. 2018, 66, 1547-1569. [CrossRef]

12. Isaac, O.; Aldholay, A.; Abdullah, Z.; Ramayah, T. Online learning usage within Yemeni higher education: The role of compatibility and task-technology fit as mediating variables in the IS success model. Comput. Educ. 2019, 136, 113-129. [CrossRef] 
13. Zhang, L.; Shao, Z.; Pan, Z.; Feng, Y. Examining Individuals' Utilization of SPOC: Extending the Task-Technology Fit Model with Online and Offline Perspective. In Proceedings of the Pacific Asia Conference on Information Systems (PACIS), X'ian, China, 8-12 July 2019.

14. Ashrafi, A.; Zareravasan, A.; Rabiee Savoji, S.; Amani, M. Exploring factors influencing students' continuance intention to use the learning management system (LMS): A multi-perspective framework. Interact. Learn. Environ. 2020, 1-23. [CrossRef]

15. Lin, Y.T. Impacts of a flipped classroom with a smart learning diagnosis system on students' learning performance, perception, and problem solving ability in a software engineering course. Comput. Hum. Behav. 2019, 95, 187-196. [CrossRef]

16. Al-Fraihat, D.; Joy, M.; Sinclair, J. Evaluating E-learning systems success: An empirical study. Comput. Hum. Behav. 2020, 102, 67-86. [CrossRef]

17. Huang, K.Y.; Nambisan, P.; Uzuner, Ö. Informational Support or Emotional Support: Preliminary Study of an Automated Approach to Analyze Online Support Community Contents. In Proceedings of the International Conference on Information Systems (ICIS) Proceedings, St. Louis, MI, USA, 12-15 December 2010.

18. Eksail, F.A.A.; Afari, E. Factors affecting trainee teachers' intention to use technology: A structural equation modeling approach. Educ. Inf. Technol. 2020, 25, 2681-2697. [CrossRef]

19. Liao, Y.W.; Huang, Y.M.; Huang, S.H.; Chen, H.C.; Wei, C.W. Exploring the Switching Intention of Learners on Social Networkbased Learning Platforms: A Perspective of the Push-Pull-Mooring Model. EURASIA J. Math. Sci. Technol. Educ. 2019, 15, $1-10$.

20. Chaka, J.G.; Govender, I. Students' perceptions and readiness towards mobile learning in colleges of education: A Nigerian perspective. South Afr. J. Educ. 2017, 37, 1-12. [CrossRef]

21. Castillo-Merino, D.; Serradell-López, E. An analysis of the determinants of students' performance in e-learning. Comput. Hum. Behav. 2014, 30, 476-484. [CrossRef]

22. Baby, A.; Kannammal, A. Network Path Analysis for developing an enhanced TAM model: A usercentric e-learning perspective. Comput. Hum. Behav. 2019. [CrossRef]

23. Ayele, A.A.; Birhanie, W.K. Acceptance and use of e-learning systems: The case of teachers in technology institutes of Ethiopian Universities. Appl. Inform. 2018, 5, 1-11. [CrossRef]

24. Chang, C.T.; Hajiyev, J.; Su, C.R. Examining the students' behavioral intention to use e-learning in Azerbaijan? The general extended technology acceptance model for e-learning approach. Comput. Educ. 2017, 111, 128-143. [CrossRef]

25. Osang, F.B.; Abinwi, N.; Tsuma, C. Reviewing Information Systems Usage and Performance Models. Int. J. Comput. Sci. Inf. Technol. 2015, 6, 476-484.

26. Scherer, R.; Siddiq, F.; Tondeur, J. All the same or different? Revisiting measures of teachers' technology acceptance. Comput. Educ. 2020, 143, 1-17. [CrossRef]

27. Weng, C.; Tsai, C.C.; Weng, A. Social support as a neglected e-learning motivator affecting trainee's decisions of continuous intentions of usage. Australas. J. Educ. Technol. 2015, 31, 177-192. [CrossRef]

28. Wu, B.; Chen, X. Continuance intention to use MOOCs: Integrating the technology acceptance model (TAM) and task technology fit (TTF) model. Comput. Hum. Behav. 2017, 67, 221-232. [CrossRef]

29. Vanduhe, V.Z.; Nat, M.; Hasan, H.F. Continuance Intentions to Use Gamification for Training in Higher Education: Integrating the Technology Acceptance Model (TAM), Social Motivation, and Task Technology Fit (TTF). IEEE Access 2020, 8, 21473-21484.

30. Pozón-López, I.; Kalinic, Z.; Higueras-Castillo, E.; Liébana-Cabanillas, F. A multi-analytical approach to modeling of customer satisfaction and intention to use in Massive Open Online Courses (MOOC). Interact. Learn. Environ. 2019, 1-19. [CrossRef]

31. Lee, M.C. Explaining and predicting users' continuance intention toward e-learning: An extension of the expectation-confirmation model. Comput. Educ. 2010, 54, 506-516. [CrossRef]

32. Zhonggen, Y.; Xiaozhi, Y. An extended technology acceptance model of a mobile learning technology. Comput. Appl. Eng. Educ. 2019, 27, 721-732. [CrossRef]

33. Al-Rahmi, W.M.; Yahaya, N.; Alamri, M.M.; Alyoussef, I.Y.; Al-Rahmi, A.M.; Kamin, Y.B. Integrating innovation diffusion theory with technology acceptance model: Supporting students' attitude towards using a massive open online courses (MOOCs) systems. Interact. Learn. Environ. 2019, 1-13. [CrossRef]

34. Sun, Y.; Gao, F. An investigation of the influence of intrinsic motivation on students' intention to use mobile devices in language learning. Educ. Technol. Res. Dev. 2020, 68, 1181-1198. [CrossRef]

35. Cheng, E.W. Choosing between the theory of planned behavior (TPB) and the technology acceptance model (TAM). Educ. Technol. Res. Dev. 2019, 67, 21-37. [CrossRef]

36. Romero-Frías, E.; Arquero, J.L.; del Barrio-García, S. Exploring how student motivation relates to acceptance and participation in MOOCs. Interact. Learn. Environ. 2020, 1-17. [CrossRef]

37. Huang, F.; Teo, T. Influence of teacher-perceived organizational culture and school policy on Chinese teachers' intention to use technology: An extension of technology acceptance model. Educ. Technol. Res. Dev. 2019, 1-21. [CrossRef]

38. Huang, F.; Teo, T.; Zhou, M. Chinese students' intentions to use the Internet-based technology for learning. Educ. Technol. Res. Dev. 2020, 68, 575-591. [CrossRef]

39. Hsu, J.Y.; Chen, C.C.; Ting, P.F. Understanding MOOC continuance: An empirical examination of social support theory. Interact. Learn. Environ. 2018, 26, 1100-1118. [CrossRef]

40. Benbasat, I.; Henri, B. Quo vadis, TAM? J. Assoc. Inf. Syst. 2007, 8, 211-218. [CrossRef] 
41. Cassel, J. The contribution of the social environment to host resistance. Am. J. Epidemiol. 1976, 104, 107-123. [CrossRef]

42. Venkatesh, V.; Thong, J.Y.; Xu, X. Consumer acceptance and use of information technology: Extending the unified theory of acceptance and use of technology. MIS Q. 2012, 36, 157-178. [CrossRef]

43. Wang, Y.; Meister, D.B.; Gray, P.H. Social influence and knowledge management systems use: Evidence from panel data. Mis $Q$. 2013, 37, 299-313. [CrossRef]

44. Cobb, S. Presidential Address-1976. Social Support as a Moderator of Life Stress. Psychosom. Med. 1976, 38, 300-314. [CrossRef]

45. Lin, J.; Li, L.; Yan, Y. Understanding Chinese consumer engagement in social commerce: The roles of social support and swift guanxi. Internet Res. 2018, 28, 2-22. [CrossRef]

46. Cheng, S.T.; Chan, A.C. The multidimensional scale of perceived social support: Dimensionality and age and gender differences in adolescents. Personal. Individ. Differ. 2004, 37, 1359-1369. [CrossRef]

47. Hung, M.L.; Chou, C.; Chen, C.H.; Own, Z.Y. Learner readiness for online-learning: Scale development and student perceptions. Comput. Educ. 2010, 55, 1080-1090. [CrossRef]

48. Harvey, P.; Sinclair, C.; Dowson, M. Teacher motivations for postgraduate study: Development of a psychometric scale for Christian higher education. Christ. High. Educ. 2005, 4, 241-264. [CrossRef]

49. Maurer, T.J.; Weiss, E.M.; Barbeite, F.G. A model of involvement in work-related learning and development activity: The effects of individual, situational, motivational, and age variables. J. Appl. Psychol. 2003, 88, 707. [CrossRef]

50. Wang, C.X.; Hu, W.D. Fine Portrait of Online Teaching in Primary and Secondary Schools under the COVID-19 Pandemic. 2020. Available online: http:/ / www.xinhuanet.com/politics/2020-04/13/c_1125846623.htm (accessed on 1 February 2021).

51. Choi, D.H.; Kim, J.; Kim, S.H. ERP training with a web-based electronic learning system: The flow theory perspective. Int. J. Hum. Comput. Stud. 2007, 65, 223-243. [CrossRef]

52. Sun, P.-C.; Tsai, R.J.; Finger, G.; Chen, Y.-Y.; Yeh, D. What drives a successful e-Learning? An empirical investigation of the critical factors influencing learner satisfaction. Comput. Educ. 2008, 50, 1183-1202. [CrossRef]

53. Cheng, Y.M. Exploring the intention to use mobile learning: The moderating role of personal innovativeness. J. Syst. Inf. Technol 2014. [CrossRef]

54. Soon, K.H.; Sook, K.I.; Jung, C.W.; Im, K.M. The effects of Internet-based distance learning in nursing. Comput. Nurs. 2000, 18, 19-25.

55. Cidral, W.A.; Oliveira, T.; Di Felice, M.; Aparicio, M. E-learning success determinants: Brazilian empirical study. Comput. Educ. 2018, 122, 273-290. [CrossRef]

56. Rodríguez-Ardura, I.; Meseguer-Artola, A. What leads people to keep on e-learning? An empirical analysis of users' experiences and their effects on continuance intention. Interact. Learn. Environ. 2016, 24, 1030-1053. [CrossRef]

57. Levy, Y.; Ramim, M.M. The e-learning skills gap study: Initial results of skills desired for persistence and success in online engineering and computing courses. In Proceeding of the Chais 2017 Conference on Innovative and Learning Technologies Research, Bologna, Italy, 26 Jun-1 July 2017; Association for Computing Machinery: New York, NY, USA, 2017; pp. 57-68.

58. Lwoga, E. Critical success factors for adoption of web-based learning management systems in Tanzania. Int. J. Educ. Dev. Using ICT 2014, 10, 4-21.

59. Goodhue, D.; Thompson, R. Task-Technology Fit and Individual Performance. MIS Q. 1995, 19, 2. [CrossRef]

60. Wu, W.C.V.; Yen, L.L.; Marek, M. Using online EFL interaction to increase confidence, motivation, and ability. J. Educ. Soc. 2011, $14,118-129$.

61. Lee, D.Y.; Lehto, M.R. User acceptance of YouTube for procedural learning: An extension of the Technology Acceptance Model. Comput. Educ. 2013, 61, 193-208.

62. Yu, T.K.; Yu, T.Y. Modelling the factors that affect individuals' utilisation of online learning systems: An empirical study combining the task technology fit model with the theory of planned behaviour. Br. J. Educ. Technol. 2010, 41, 1003-1017. [CrossRef]

63. Lin, W.S.; Wang, C.H. Antecedences to continued intentions of adopting e-learning system in blended learning instruction: A contingency framework based on models of information system success and task-technology fit. Comput. Educ. 2012, 58, 88-99. [CrossRef]

64. Chang, H.H. Task-technology fit and user acceptance of online auction. Int. J. Hum. Comput. Stud. 2010, 68, 69-89. [CrossRef]

65. Lu, H.P.; Yang, Y.W. Toward an understanding of the behavioral intention to use a social networking site: An extension of task-technology fit to social-technology fit. Comput. Hum. Behav. 2014, 34, 323-332. [CrossRef]

66. Kim, M.J.; Chung, N.; Lee, C.K.; Preis, M.W. Motivations and use context in mobile tourism shopping: Applying contingency and task-technology fit theories. Int. J. Tour. Res. 2015, 17, 13-24. [CrossRef]

67. Castañeda, J.A.; Muñoz-Leiva, F.; Luque, T. Web Acceptance Model (WAM): Moderating effects of user experience. Inf. Manag. 2007, 44, 384-396. [CrossRef]

68. Wang, K.; Lin, C.L. The adoption of mobile value-added services. Manag. Serv. Qual. Int. J. 2012, 22, 184-208. [CrossRef]

69. Venkatesh, V.; Davis, F.D. A theoretical extension of the technology acceptance model: Four longitudinal field studies. Manag. Sci. 2000, 46, 186-204. [CrossRef]

70. Wu, B.; Zhang, C. Empirical study on continuance intentions towards E-Learning 2.0 systems. Behav. Inf. Technol. 2014, 33, 1027-1038. [CrossRef]

71. Teo, T.; Zhou, M. Explaining the intention to use technology among university students: A structural equation modeling approach. J. Comput. High. Educ. 2014, 26, 124-142. [CrossRef] 
72. Alraimi, K.M.; Zo, H.; Ciganek, A.P. Understanding the MOOCs continuance: The role of openness and reputation. Comput. Educ. 2015, 80, 28-38. [CrossRef]

73. Shao, Z. Examining the impact mechanism of social psychological motivations on individuals' continuance intention of MOOCs. Internet Res. 2018, 28. [CrossRef]

74. Barki, H.; Hartwick, J. Measuring User Participation, User Involvement, and User Attitude. MIS Q. 1994, 18, 59-79. [CrossRef]

75. Hackbarth, G.; Grover, V.; Mun, Y.Y. Computer playfulness and anxiety: Positive and negative mediators of the system experience effect on perceived ease of use. Inf. Manag. 2003, 40, 221-232. [CrossRef]

76. Dishaw, M.T.; Strong, D.M. Extending the Technology Acceptance Model with Task-technology Fit Constructs. Inf. Manag. 1999, 36, 9-21. [CrossRef]

77. Venkatesh, V.; Morris, M.G.; Davis, G.B.; Davis, F.D. User acceptance of information technology: Toward a unified view. MIS Q. 2003, 425-478. [CrossRef]

78. Ifenthaler, D.; Schweinbenz, V. Students' acceptance of tablet PCs in the classroom. J. Res. Technol. Educ. 2016, 48, 306-321. [CrossRef]

79. Van Deursen, A.J.; Ben Allouch, S.; Ruijter, L.P. Tablet use in primary education: Adoption hurdles and attitude determinants. Educ. Inf. Technol. 2016, 21, 971-990. [CrossRef]

80. Zheng, J.; Li, S. What drives students' intention to use tablet computers: An extended technology acceptance model. Int. J. Educ. Res. 2020, 102, 101612. [CrossRef]

81. Gefen, D.; Karahanna, E.; Straub, D.W. Trust and TAM in online shopping: An integrated model. MIS Q. 2003, 27, 51-90. [CrossRef]

82. Mohammadi, H. Investigating users' perspectives on e-learning: An integration of TAM and IS success model. Comput. Hum. Behav. 2015, 45, 359-374. [CrossRef]

83. Lin, C.L.; Jin, Y.Q.; Zhao, Q.; Yu, S.W.; Su, Y.S. Factors Influence Students' Switching Behavior to Online Learning under COVID-19 Pandemic: A Push-Pull-Mooring Model Perspective. Asia Pac. Educ. Res. 2021, 1-17. [CrossRef]

84. Su, Y.S.; Wu, S.Y. Applying data mining techniques to explore users behaviors and viewing video patterns in converged IT environments. J. Ambient Intell. Hum. Comput. 2021, 1-8. [CrossRef]

85. Cheng, P.; OuYang, Z.; Liu, Y. Understanding bike sharing use over time by employing extended technology continuance theory. Transp. Res. Part A Policy Pract. 2019, 124, 433-443. [CrossRef]

86. Hair, J.F.; Risher, J.J.; Sarstedt, M.; Ringle, C.M. When to use and how to report the results of PLS-SEM. Eur. Bus. Rev. 2019. [CrossRef]

87. Shiau, W.L.; Sarstedt, M.; Hair, J.F. Internet research using partial least squares structural equation modeling (PLS-SEM). Int. Res. 2019, 29, 398-406. [CrossRef]

88. Su, Y.S.; Lai, C.F. Applying educational data mining to explore viewing behaviors and performance with flipped classrooms on the social media platform Facebook. Front. in Psychol. 2021, 12, 653018. [CrossRef]

89. Su, Y.S.; Chen, H.R. Social Facebook with big six approaches for improved students' learning performance and behavior: A case study of a project innovation and implementation course. Front. Psychol. 2020, 11, 1166. [CrossRef] [PubMed]

90. Su, Y.-S.; Ding, T.-J.; Chen, M.-Y. Deep Learning Methods in Internet of Medical Things for Valvular Heart Disease Screening System. IEEE Internet Things J. 2021, 1. [CrossRef]

91. Hair, J.; Hollingsworth, C.L.; Randolph, A.B.; Chong, A.Y.L. An updated and expanded assessment of PLS-SEM in information systems research. Ind. Manag. Data Syst. 2017, 117, 442-458. [CrossRef]

92. Fornell, C.; Larcker, D.F. Structural Equation Models with Unobservable Variables and Measurement Error: Algebra and Statistics. J. Mark. Res. 1981, 12, 382-388. [CrossRef]

93. Park, S.Y. An analysis of the technology acceptance model in understanding university students' behavioral intention to use e-learning. J. Educ. Technol. Soc. 2009, 12, 150-162.

94. Roca, J.C.; Gagné, M. Understanding e-learning continuance intention in the workplace: A self-determination theory perspective. Comput. Hum. Behav. 2008, 24, 1585-1604. [CrossRef]

95. Jin, Y.Q.; Lin, C.L.; Zhao, Q.; Yu, S.W.; Su, Y.S. A study on traditional teaching method transferring to e-learning under the Covid-19 pandemic: From Chinese students' perspectives. Front. Psychol. 2021, 12, 632787. [CrossRef]

96. Su, Y.-S.; Chou, C.-H.; Chu, Y.-L.; Yang, Z.-Y. A finger-worn device for exploring Chinese printed text with using CNN algorithm on a micro IoT processor. IEEE Access 2019, 7, 116529-116541. [CrossRef]

97. Su, Y.S.; Suen, H.Y.; Hung, K.E. Predicting behavioral competencies automatically from facial expressions in real-time video recorded interviews. J. Real Time Image Process. 2021, 1-11.

98. Su, Y.-S.; Lin, C.-L.; Chen, S.-Y.; Lai, C.-F. Bibliometric study of social network analysis literature. Libr. Hi Tech 2019, 38, 420-433. [CrossRef] 